Vol 4 No 1 Tahun 2019 (60-67)
JurnalTerapanIlmuKeolahragaan
$\mathrm{http} / / /$ ejournal.upi.edu/index.php/JTIKOR/

\title{
Media Development Study Basic Techniques of Handball Ball Based Adobe Flash Player on Coaching Extracurricular Son Handball Junior High School Level in Demak District
}

Akhmad Sa'dullah ${ }^{\square}$, Agus Kristiyanto, Sapta Kunta Purnama

Post-graduate of Sport Science, University of Sebelas Maret

Kata Kunci:

Multimedia Learning, handball, adobe flash player

\section{Abstract}

The background of this research is the unavailability of learning model of basic technique of hand ball which is used as a reference to build the ability of basic technique of hand ball among the students. The purpose of this research is to develop the basic technique of handball based technique of handball based on adobe flash player, including opening, passing, catch the ball, dribble, blocking, shoot the ball, goalkeeper training and stretching, all of which are arranged in one easily accessible media anytime, by anyone and anywhere, especially at the Se-degree Junior High School in Demak district. The research method used is "Reasearch and Developement" approach. "This research is a research and development through preliminary stage, development of learning design, production, and product evaluation. After the production phase, then the initial product validation stage by media experts, academicians and practitioners. The evaluation results of media experts for the assessment component containing aspects of text, images / photos, sound audio, video obtained $61 \%$ of the total for the feasibility conclusion of the product. The results of the evaluation of academicians for the assessment component containing aspects of conformity, usefulness, security, and aspects of implementation are $85.71 \%$ of the total for the feasibility conclusion of the product. The results of the expert evaluation of practitioners for the assessment component containing aspects of conformity, usefulness, security, and the implementation aspect obtained $97.86 \%$ of the total for the feasibility conclusion of the product. The final percentage of all experts is $81.58 \%$ and it can be interpreted that the design of Adobe Flash Player based hand baseball technique technique can be tested in the next step. Small group test results for the assessment component that contains aspects of conformity, usefulness, security, and aspects of implementation obtained $71.25 \%$ of the overall for the feasibility of the conclusion of the product. The results of the large group test for the assessment component that contains aspects of conformity, usefulness, security, and the implementation aspect obtained $87.92 \%$ of the overall for the feasibility conclusion of the product. Based on the specified criteria it can be concluded that Adobe Flash Player's handmade basic ballast technique technique products are valid and usable. This is because the data results are stretched $80-100 \%$ for clarification of product feasibility percentage. Therefore this product is feasible and effective to develop the extracurricular handmade coaching in Demak Regency. 


\section{INTRODUCTION}

The popularity of Ball sports in Demak Regency is visible from the existing facilities and infrastructure as well as the hand-held ballast activities among students. Every player and handball coach certainly wants a high achievement, therefore from the popularity of handball sport in Demak Regency need to use the media training based on Adobe Flash Player where the media of this exercise contains about the models of the basic technique of handball for helps the understanding for trainers and athletes in the process of training and exercising basic ball technique skills. Activities provided in teaching or training methods should be didactic touches, so that the activities performed can achieve the teaching objectives. Physical activity trains a skill not just like the teaching and learning activities that are in the classroom every day, but rather the fulfillment of student movement needs. Fulfilling this need is very important, because motion is the only stimulus for the physical development of students. In the above case it can be concluded that the guidance teacher or coach handling in the handmade extracurricular activities of Demak Regency has not been able to explore the models of basic technique exercises and provide models of exercises that get the didactic touches and pedagogical principles in the practice, and using media in the training process. Therefore the researchers took the initiative to provide development for basic ball technique training techniques to help the understanding of coaches or extracurricular trainers in training the basic techniques of handball. Handball games have basic techniques to be mastered by every Handball player to support his performance during the game.

The basic techniques of Handball are, passing, dribbling by bouncing to the floor (dribble), catching the ball upon receiving the catch, throwing the ball towards the goal (shooting), and blocking the opponent's attack with how to block the opponent's ball shot by hand, and blocking the movement of the opponent (block). With the development of media model of basic hand ball technique based on adobe flash player, it is expected that the students who follow in the handball extracurricular activity can improve their basic technique skill, and can create the candidates for the achieving young athlete.

\section{METHOD}

The development model used by researchers is the development and research model according to Borg and Gall (1983: 75). The selection of this model is due to compatibility with the researcher's development with Borg and Gall's research and development model. The steps in this development model are as follows:
a. Research and information collecting
b. Planning
c. Develop preliminary from of product
d. Preliminary field testing
e. Main product revision
f. Main field testing
g. Operational product revision
h. Operational field testing
i. Final Product Revision
j. Dissemination and implementation

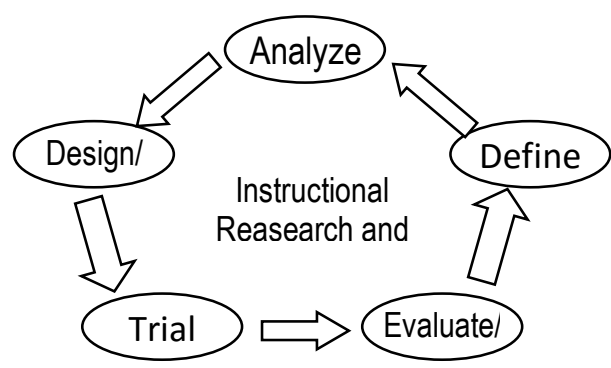

Figure 1. Model Development Cycle Borg and Gall (1989: 782)

From the ten steps of the development model proposed by Borg and Gall there are several stages that are partially modified by the researcher, with consideration of time, effort, and limited costs to produce a model development product of the basic technique of passing ball sports. To know the improvement of the product development, the researcher conducted experiments on the model of exercise product to improve the basic passing technique skills.

In the procedure the basic exercise technique model passes on the sport of handball, carried out through several stages of this procedure as follows: 


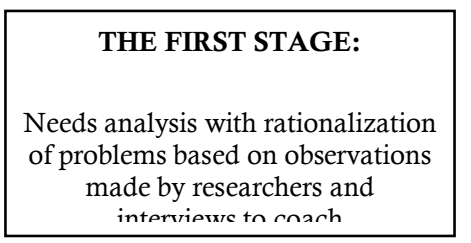

SECOND STAGE:

\begin{tabular}{|c|c|c|}
\hline $\begin{array}{l}\text { The study of } \\
\text { basic } \\
\text { technical } \\
\text { theories pass } \\
\text { the ball hand }\end{array}$ & $\begin{array}{l}\text { Forms of basic } \\
\text { ball technique } \\
\text { techniques }\end{array}$ & $\begin{array}{l}\text { The design of } \\
\text { the medium of } \\
\text { the basic } \\
\text { technique of } \\
\text { handball }\end{array}$ \\
\hline
\end{tabular}

THIRD PHASE:

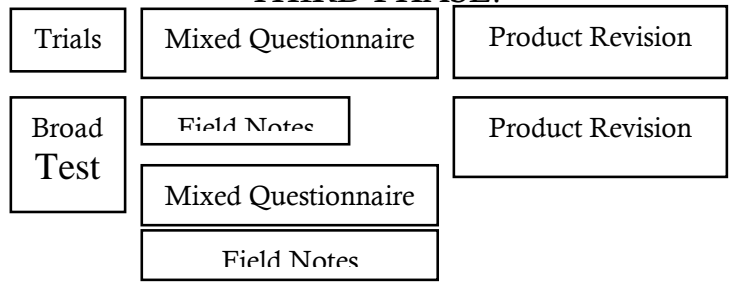

Figure 2. Flow Chart of Development Procedure

\section{RESULT AND DISCUSSION}

Physical education is a process of learning through physical activity designed to improve physical fitness, develop motor skills, knowledge, healthy living behavior, active, sportsmanship, and emotional intelligence (AdangSuherman, 2000: 1).Research development begins with a preliminary stage of study which is an early stage in research that is problem or problem. Audio media is a medium whose use emphasizes the aspect of hearing. So the sense of hearing is central to the use of this medium. The use of this medium, the message delivered is poured into auditive symbols, both verbal (spoken / verbal) and nonverbal (Angkowo, 2007: 13). Sports Handball is a team sport that played two teams with each team amounted to 7 people. The goal inside the Handball game is to enter the ball into the opposing goal as much as possible and resist the opponent's attack so as not to put the ball into the net. How to play Handball Sport is to move the ball into one position to another using the hands, which intend to give the ball to a teammate to work together to move the ball from the game area itself, to the opposing game area in order to make points or score goals According Muhlisin (2016: 2).The preliminary study phase is the starting point for the problem to be solved. From this stage, will be obtained information and direction of development goals that will be done. Problems that have been identified by the next researcher will be used as scope to limit the problems in the research process. The scope process has been formulated and then formulated the process to be implemented in the research process based on theoretical studies in accordance with the research. Furthermore, the researchers will carry out two stages: the literature study stage and data analysis of the preliminary results.

This stage is done aims to get a theoretical study that underlies about the problems obtained. The process of needs analysis is made one way to know, compile and solve the problems found. Literature study is the stage of strengthening the theoretical foundations that become material to be strengthened.

The process of needs analysis includes several processes that will be implemented so that ultimately get conclusions in this stage. The first stage of the research done in the early stages is to determine the subject matter that exist in the subject. The method used by researchers in obtaining the subject matter that occurs is by the method of interviews with related parties such as trainers / coaches ektrakurikuler handball in the environment of Junior high school in Demak District. The interview process undertaken by the researcher was preceded by the observation process of several meetings. From the process of observation is determined meeting schedule with several related parties, including coaches and some hand ball athletes. Interview conducted during routine exercise so that researchers can obtain complete information. Questions in the interview process start from the purpose of coaching, the training process, the obstacles in the field, and the training program.

The results of the interviews resulted in several conclusions such as the exercise program process has been running well, this can be seen from the activities of the exercise process that is physical exercise and technical training. Variations in the training of basic techniques have been given to the athlete to give pleasure in the exercise so that athletes are not easily bored in the training process. The use of innovations that have never done exercise to make the training process less interesting and difficult to understand by students

The obstacles that are often encountered in the field by the extracurricular handball coach is the lack of facilities and infrastructure become one of 
the barrier of the training process, for example the lack of balls so less effective in the process of training. In addition, students have not understood how to play or basic techniques of the game, so the need to create a video-based media to facilitate the trainer / coach extracurricular handball in carrying out routine exercise activities so that students can easily understand and the objectives of the exercise program can be achieved well .

The underlying conclusion of the researcher is to make a decision to use this type of development research to solve the problems that occur. In addition, research development is used by researchers because the processes in developing the product is based on studies of several parties such as trainers and academicians. Expected from the process, researchers are able to develop an appropriate product to overcome and provide a breakthrough that is able to become one of the benchmarks for further development.

Researchers hope that the resulting product can bring innovative workouts, and the creation of a fun workout process that can motivate students to have more opportunity to explore the basic techniques of handmade exercises and can move widely and freely in accordance with the level of ability they have, is expected to improve basic ball technique skills on students. The resulting product is also expected to assist the coach / coach extracurricular handball in providing various training materials using these produced products.

After going through the process of design and production, then produced the initial product development of Basic Technique Sport Handball Handball Based Adobe Flash Player. In accordance with the steps in the process of training the initial product draft of the development of Basic Techniques of Sports Ball Design Based on Adobe Flash Player as follows:

a) General Materials of Handball Ball Knowledge.

b) Handball Streaching Material.

c) Exercise Material Basic Hand Passing Handball Technique.

d) Basic Hand Catch Handwriting Techniques.

e) Basic Hand Dribbling Technique Training Material Handball.

f) Basic Handball Technique Material Handball Blocking. g) Basic Hand Training Techniques Shooting Handball.

h) Handball Goalkeeping Exercise Materials.

i) Rules of Game Handball and Situational Game.

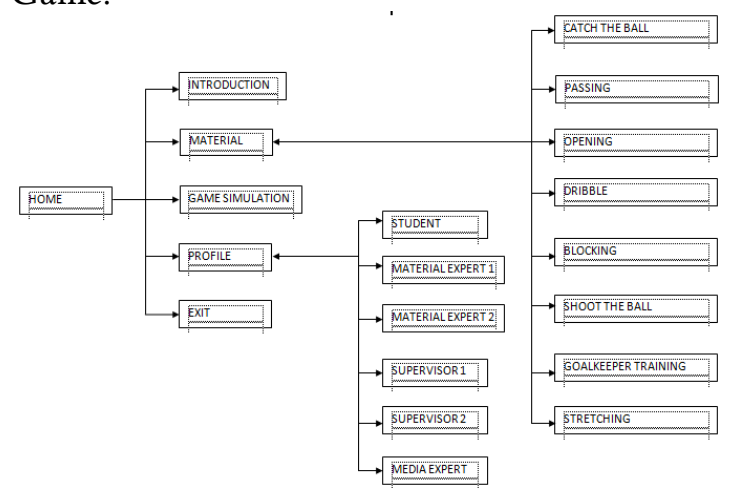

Figure 3. Flow Chart Of Application Of Handball Techniques Learning Media Based On Adobe Flash Player

\section{A. Data Analysis and Study Results Introduction}

After the researcher undertook the preliminary study phase, the researcher followed up with some notes from each coach / coach extracurricular handball in the junior / equivalent school environment in Demak district. In essence, most coaches / handball coaches have never used interactive media in the training process, so most students still find it difficult to understand the basic technical movements that are good and correct, as well as how they play.In the interview session, the trainers explained that there were difficulties to develop the basic techniques of handmade exercises due to the limited facilities and infrastructure, besides the students were difficult to practice and understand the basic techniques of handmade because there is no media training to facilitate or assist students in practicing and improving the basic techniques of handball movement, so that in the routine exercise process becomes less maximal.

\section{B. Product Development \\ 1. Theory Study}

The product development stage consists of an assessment of supporting theories about exercise media and basic ball exercises as well as the initial drafting stage of product development. Theoretical assessment is needed to underlie the preparation of products which in this case is a product of the development of Basic Flash Sports Techniques Training 
Handball Based Adobe Flash Player. The theories used are the general theory of Handball knowledge and the theory of basic engineering exercises, and the supporting aspects of the theory of practice.

\section{Initial Product Design}

After going through the process of design and production, then produced the initial product development of Basic Technique Sport Handball Handball Based Adobe Flash Player. In accordance with the steps in the process of training the initial product draft of the development of Basic Techniques of Sports Ball Design Based on Adobe Flash Player as follows:

a) General Materials of Handball Ball Knowledge.

b) Handball Streaching Material.

c) Exercise Material Basic Hand Passing Handball Technique.

d) Basic Hand Catch Handwriting Techniques.

e) Basic Hand Dribbling Technique Training Material Handball.

f) Basic Handball Technique Material Handball Blocking.

g) Technical Training Material

h) a Hand.

i) Rules of Game Handball and Situational Game Game.

The following will be presented in the draft of the initial product development of Basic Flash Sports Techniques Training Handball Based Adobe Flash Player for students in Junior High School / equivalent environment before being validated by media experts and material experts:

Table 1. Evaluation Results of Media Experts

\begin{tabular}{|c|c|c|c|c|c|}
\hline $\begin{array}{l}\mathrm{N} \\
\mathrm{o}\end{array}$ & $\begin{array}{c}\text { Assessmen } \\
\text { t } \\
\text { Componen } \\
\text { ts }\end{array}$ & $\begin{array}{l}\text { Result } \\
\text { s } \\
\text { Score }\end{array}$ & $\begin{array}{l}\text { Maximu } \\
\text { m Score }\end{array}$ & $\begin{array}{l}\text { Percenta } \\
\text { ge }\end{array}$ & Category \\
\hline 1 & Text & 12 & 20 & $60 \%$ & $\begin{array}{c}\text { ENOUG } \\
\text { H } \\
\text { VALID }\end{array}$ \\
\hline 2 & $\begin{array}{l}\text { Picture / } \\
\text { Image }\end{array}$ & 15 & 25 & $60 \%$ & $\begin{array}{c}\text { ENOUG } \\
\text { H } \\
\text { VALID }\end{array}$ \\
\hline 3 & $\begin{array}{l}\text { Audio } \\
\text { Sound }\end{array}$ & 7 & 10 & $70 \%$ & $\begin{array}{c}\text { ENOUG } \\
\text { H } \\
\text { VALID }\end{array}$ \\
\hline 4 & Video & 18 & 30 & $60 \%$ & $\begin{array}{c}\text { ENOUG } \\
\text { H } \\
\text { VALID }\end{array}$ \\
\hline & Total & 52 & 85 & $61 \%$ & $\begin{array}{c}\text { ENOUG } \\
\text { H } \\
\text { VALID }\end{array}$ \\
\hline
\end{tabular}

Table 2. Evaluation Results of Academicians

\begin{tabular}{cccccc}
\hline $\begin{array}{c}\mathrm{N} \\
\mathrm{o}\end{array}$ & $\begin{array}{c}\text { Assessment } \\
\text { Components }\end{array}$ & $\begin{array}{c}\text { Resul } \\
\text { ts } \\
\text { Score }\end{array}$ & $\begin{array}{c}\text { Maximu } \\
\mathrm{m} \mathrm{Scor}\end{array}$ & $\begin{array}{c}\text { Percent } \\
\text { age }\end{array}$ & $\begin{array}{c}\text { Categor } \\
\mathrm{y}\end{array}$ \\
\hline 1 & Aspect of Conformity & 32 & 35 & $91.43 \%$ & Valid \\
2 & Aspects of Utilization & 27 & 35 & $77 \%$ & Valid \\
3 & Security Aspects & 33 & 35 & $94.29 \%$ & Valid \\
4 & Aspects of Discretion & 28 & 35 & $80.00 \%$ & Valid \\
\hline & Total & 120 & 140 & $85.71 \%$ & Valid \\
\hline
\end{tabular}

Researchers using a prewriter aim to increase the quality of the developed product.

Table 3. Evaluation Results of Practitioners

\begin{tabular}{|c|c|c|c|c|c|}
\hline & $\begin{array}{c}\text { Assessment } \\
\text { Component } \\
\mathrm{s}\end{array}$ & $\begin{array}{l}\text { Result } \\
\text { s } \\
\text { Score }\end{array}$ & $\begin{array}{c}\text { Maximu } \\
\mathrm{m} \text { Scor }\end{array}$ & $\begin{array}{c}\text { Percentag } \\
\mathrm{e}\end{array}$ & $\begin{array}{c}\text { Categor } \\
\mathrm{y}\end{array}$ \\
\hline 1 & $\begin{array}{c}\text { Aspect of } \\
\text { Conformity }\end{array}$ & 34 & 35 & $97.14 \%$ & Valid \\
\hline 2 & $\begin{array}{l}\text { Aspects of } \\
\text { Utilization }\end{array}$ & 35 & 35 & $100 \%$ & Valid \\
\hline 3 & $\begin{array}{l}\text { Security } \\
\text { Aspects }\end{array}$ & 34 & 35 & $97.14 \%$ & Valid \\
\hline 4 & $\begin{array}{l}\text { Aspects of } \\
\text { Discretion }\end{array}$ & 34 & 35 & $97.14 \%$ & Valid \\
\hline & Total & 137 & 140 & $97.86 \%$ & Valid \\
\hline
\end{tabular}

The overall data obtained from the expert evaluation can be concluded that the product is valid and feasible to be tested at the stage of product effectiveness. Of course before applied, previous researchers pay attention to the input of the expert handball so that the product better. In Table 3. it can be presented quantitative data from the evaluation results of the three expert handmills:

\begin{tabular}{lcccc}
\hline No & Ahli & SkorHasil & SkorMaks & Presentase \\
\hline 1. & Media & 52 & 85 & $61.18 \%$ \\
2. & $\begin{array}{c}\text { Expert } \\
\text { Expert }\end{array}$ & 120 & 140 & $85.71 \%$ \\
Academics & $\begin{array}{c}\text { Acactitioner } \\
\text { Expert }\end{array}$ & 137 & 140 & $71,15 \%$ \\
\hline & Total & 309 & 365 & $81,58 \%$ \\
\hline
\end{tabular}

In Table 3. above the data obtained by the end of the percentage is $81.58 \%$ and can be interpreted that the product design of basic techniques of ball technique based on Adobe Flash Player can be tested in the next step. This is based on the classification of Maksum (2009: 57). 


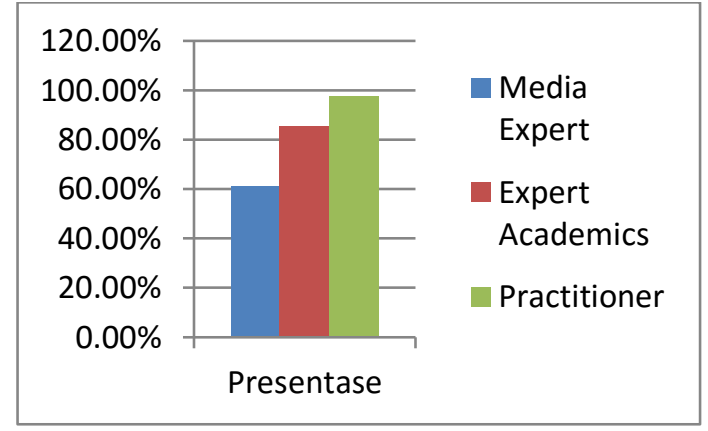

Figure 3. Recapitulation Chart of Expert Test Score Results

Tabel 4. Percentage of Evaluation Results (Maksum, 2009: 57)

\begin{tabular}{cc}
\hline Percentage Description & Percentage Description \\
\hline $80 \%-100 \%$ & Valid / use \\
$60 \%-79 \%$ & Self Valid / use \\
$50 \%-59 \%$ & Less Valid / replaced \\
$<50 \%$ & Invalid / diagnostic \\
\hline
\end{tabular}

The results of the analysis conducted by researchers in the form of qualitative and quantitative data. From these two data can be concluded that the design of products that have been designed can be continued next step. Suggestions and inputs obtained from experts are points that are considered and followed up so that the product design is more appropriate.

\section{Implementation of Field Trial}

The revised product design is followed up by the next stage of the field trial. This stage is the core of the preparation of product development design in this research. In addition, in this stage the researcher will get an assessment of the teachers of Junior High School / Equal in Demak Regency who became the subject. The subject of this research is located in MTsNKarang Tengah KabupatenDemak, each of which amounts to 4 teachers. The following will explain the results of field trials of Adobe Flash Player based hand baseball technique development media products through limited trials and extensive trials.

\section{Small Group Test}

At this stage, the researcher uses subjects of junior high school teachers / equivalents in Demak District, which are 4 teachers. Implementation of small group trials in the first week of November 2017 at MTsNKarangTenganDemak District. Implementation of small group testing begins the researchers from explaining the mechanisms in the explanation of the objectives of the activity and filling the questionnaire.

\begin{tabular}{|c|c|c|c|c|}
\hline No & Aspect of Evaluation & $\begin{array}{c}\left(\sum\right. \\
X) \\
N= \\
4\end{array}$ & $\left(\sum_{i} \mathrm{X}\right.$ & $\begin{array}{c}\text { Percentage ( } \\
\%)\end{array}$ \\
\hline 1. & $\begin{array}{c}\text { The aspect of ease is } \\
\text { understood }\end{array}$ & 43 & 60 & $71.67 \%$ \\
\hline 2. & $\begin{array}{c}\text { Aspects of ease of } \\
\text { doing }\end{array}$ & 42 & 60 & $70.00 \%$ \\
\hline 3. & Aspect of attractiveness & 45 & 60 & $75.00 \%$ \\
\hline 4. & Aspect of benefit & 41 & 60 & $68.33 \%$ \\
\hline & Jumlah & 171 & 240 & $71,25 \%$ \\
\hline
\end{tabular}

Information :
$\mathrm{N}$
$(\Sigma X)$
: Number of Subjects
$(\Sigma \mathrm{X} \mathrm{I})$
: Results Score
(\%)
: Maximum Score
: Percentage of Results

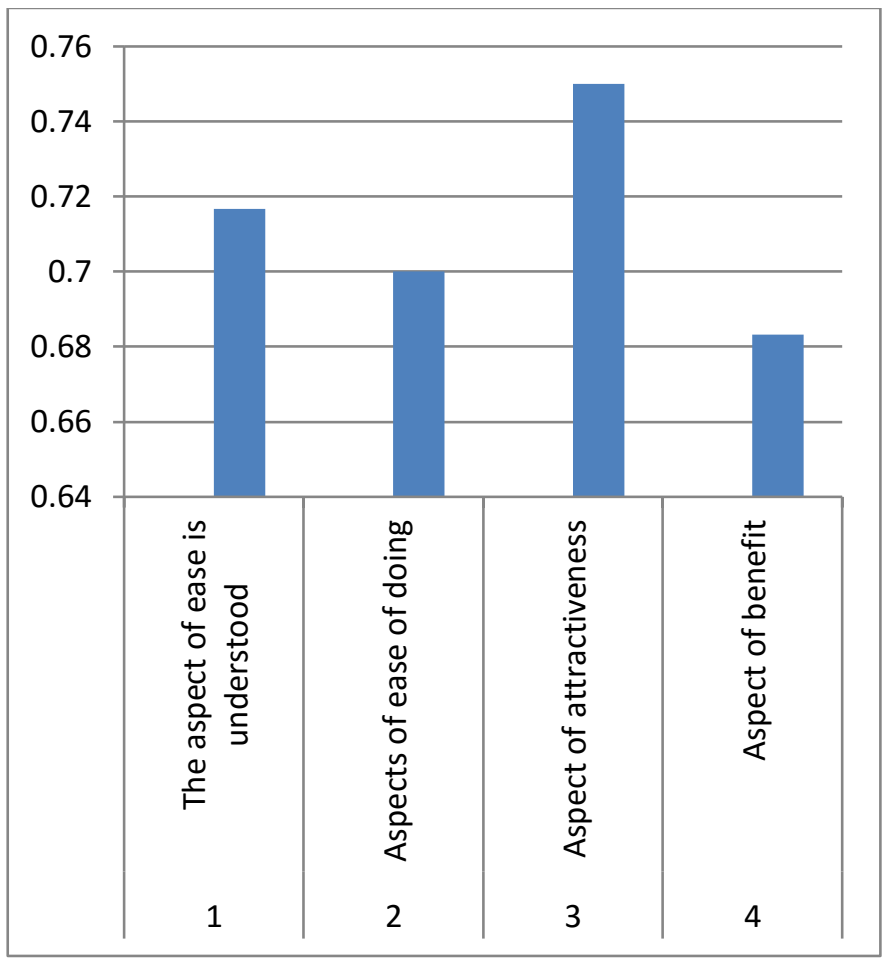

Figure 4. Recapitulation results of small group Test

In Table 4.6 it can be explained that the results of small group testing in this development study can be categorized as valid and usable. Obviously it refers to the criteria used by researchers. So that the conclusion that has been done at this stage based on theory and valid data. 
After the researchers get the data and inputs from the subject and the trainer, the next researcher revised the products that have been designed.

\section{Big Group Test}

Evaluation conducted from the previous test results serve as a reference for the next stage. The implementation of this phase was carried out in December 2017 at MTsNKarang Tengah KabupatenDemak. The number of subjects used in this phase is 8 teachers of junior / equivalent in Demak District. As in the small group test phase, the researcher gives an explanation to the subject about filling the questionnaire.

Tabel 4.7 Presentation of Quantitative Data of Large Group Test Results

\begin{tabular}{|c|c|c|c|c|}
\hline No & $\begin{array}{l}\text { Aspect of } \\
\text { Evaluation }\end{array}$ & $\begin{array}{c}\left(\sum\right. \\
X) \\
N \\
=8\end{array}$ & $\begin{array}{l}\left(\sum\right. \\
\mathrm{Xi} \\
)\end{array}$ & $\begin{array}{c}\text { Precentage } \\
(\%)\end{array}$ \\
\hline 1. & $\begin{array}{l}\text { The aspect of } \\
\text { ease is } \\
\text { understood }\end{array}$ & 97 & 120 & $80.83 \%$ \\
\hline 2. & $\begin{array}{c}\text { Aspects of } \\
\text { ease of doing }\end{array}$ & 105 & 120 & $87.50 \%$ \\
\hline 3. & $\begin{array}{c}\text { Aspect of } \\
\text { attractiveness }\end{array}$ & 110 & 120 & $91.67 \%$ \\
\hline \multirow[t]{2}{*}{4.} & $\begin{array}{c}\text { Aspect of } \\
\text { benefit }\end{array}$ & 110 & 120 & $91.67 \%$ \\
\hline & Result & 422 & 480 & $87.92 \%$ \\
\hline
\end{tabular}

Information :

$\begin{array}{ll}\mathrm{N} & : \text { Number of Subjects } \\ (\Sigma \mathrm{X}) & : \text { Results Score } \\ (\Sigma \mathrm{X}) & : \text { Maximum Score } \\ (\%) & : \text { Percentage of Results }\end{array}$

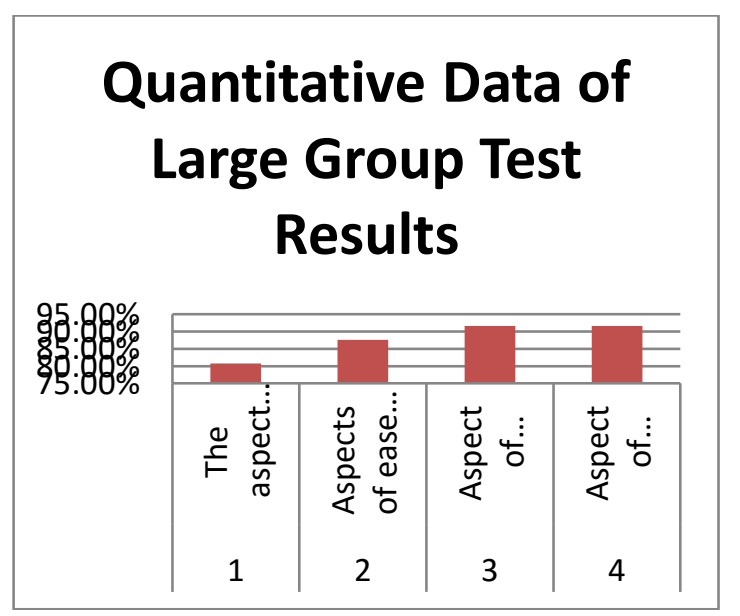

Figure 4. Recapitulation results of large group Test

Tabel 4.8 Percentage of Evaluation Results (Maksum, 2009: 57 )

\begin{tabular}{cc}
\hline Precentage & Percentage Description \\
\hline $80 \%-100 \%$ & Valid / use \\
$60 \%-79 \%$ & Self Valid / use \\
$50 \%-59 \%$ & Less Valid / replaced \\
$<50 \%$ & Invalid / diagnostic \\
\hline
\end{tabular}

In Table 4.7 it can be concluded that the designed product can proceed to the next stage. The percentage obtained indicates that the entry in the category is valid and usable. However, in this stage the researcher also receives inputs from the subject and the trainer. The results of data and inputs are accommodated by penelti before performing the effectiveness test phase of the product so it is expected that the product is really capable to be done and understood by the subject.

Characteristics of the sample is something that can not be separated from the researcher's attention. So researchers really should make an interesting product for the subject. The developed product should contain the element of the basic right technique training so that all aspects can be achieved.

\section{Final Product Revision}

Results of responses from the subjects after the implementation of extensive testing can be concluded that the design of products prepared by researchers can be accepted and then can be continued ketahap effectiveness test. The conclusion is derived from the overall stages of evaluation and analysis conducted by researchers. In addition, responses from experts are data that support the conclusion of the product design.

\section{Conclusions and recommendations}

Preliminary stage is to determine the course, identify the needs, then determine the material to be incorporated into multimedia learning products. The second stage is to develop a learning design by identifying competency standards and basic competencies, identifying student behavior and characteristics, developing materials, developing test items and learning strategies, 
then developing evaluation. Furthermore, the production stage that is, create a flow chart, compile the script, collect materials that will be incorporated into the multimedia learning, then continued the process of developing multimedia learning soccer game course. In the process of developing this learning multimedia also includes the making of its application and the process of making video learning basic handball skills. The last stage is, evaluation or validation process by material experts, media experts and sports teachers. Then in the end produce the end product in the form of multimedia learning hand ball game for students in Demak district.

The results of the expert assessment of the material about the quality of multimedia learning Media Training Basic Techniques Handball Ball Based Adobe Flash Player in Demak District is included in the criteria of "very good", according to media experts on the quality of multimedia learning is the evaluation of media experts for the assessment component that contains aspects text, images / photos, audio sound, video obtained $61 \%$ of the total for the conclusion of the feasibility of the product. The results of the evaluation of academicians for the assessment component containing aspects of conformity, usefulness, security, and aspects of implementation are $85.71 \%$ of the total for the feasibility conclusion of the product. The results of the expert evaluation of practitioners for the assessment component containing aspects of conformity, usefulness, security, and the implementation aspect obtained $97.86 \%$ of the total for the feasibility conclusion of the product. the final result data is $81.58 \%$ and it can be interpreted that the design of Adobe Flash Player based hand baseball technique technique can be tested in the next step.

Small group test results for the assessment component that contains aspects of conformity, usefulness, security, and aspects of implementation obtained $71.25 \%$ of the overall for the feasibility of the conclusion of the product. The results of the large group test for the assessment component that contains aspects of conformity, usefulness, security, and the implementation aspect obtained $87.92 \%$ of the overall for the feasibility conclusion of the product. Based on the specified criteria it can be concluded that Adobe Flash Player's handmade basic ballast technique technique products are valid and usable. This is because the result of data is stretched $80-100 \%$ for classification of product feasibility percentage.

For the next researcher who will develop Basic Flash Sports Technique Techniques Handball Based Adobe Flash Player in Demak District can be developed:

1. Improve the visual appearance of the media becomes more interesting with the new layout.

2. Can be added material by using video about the application of taught material such as motion errors about various techniques in the game of handball as evaluation of basic technique movements in the handball.

\section{Bibliography}

AdangSuherman. 2000. Dasar-dasarPenjaskes. Jakarta :Depdikbud.

Angkowo, R, A. Kosasih (2007). Optimalisasi Media Pembelajaran. Jakarta : PT Grasindo.

Bogg, W \& Gall, M.D. 1983. Educational ReserchAn Introduction. New York : Longman

Maksum, A. 2009.

MetodologiPenelitiandalamOlahraga.Surabaya :FakultasIlmuKeolahragaanUniversitasNeger i Surabaya.

Muchlisin, JokoPranawaAdi. 2016. MetodedanDasar-dasar Handball (Method and Basics Handball). Semarang: CV. PresisiCipta 